\title{
KEBERAGAMAN PARIWISATA DAN BUDAYA SEBAGAI IDENTITAS MASYARAKAT \\ (STRATEGI KOMUNIKASI PEMASARAN DINAS PARIWISATA, PEMUDA DAN OLAHRAGA DI KOTA SINGKAWANG)
}

\author{
Dea Varanida ${ }^{1}$ \\ ${ }^{1}$ Program Studi IImu Komunikasi Universitas Tanjungpura
}

Naskah diterima tanggal 23-11-2019, direvisi tanggal 24-11-2019, disetujui tanggal 26-11-2019

\begin{abstract}
Abstrak. Sebagian besar setiap daerah di Indonesia saat ini telah menyadari akan pentingnya pariwisata untuk kemajuan dalam mengembangkan potensi daerahnya. Bukan hanya untuk memajukan pariwisata, namun juga untuk pertumbuhan ekonomi bagi masyarakat daerah tersebut. Kemudian dari pada itu, pariwisata juga sudah tidak seperti dahulu lagi namun semakin berkembang maknanya bukan hanya untuk berekreasi semata tapi sudah semakin luas artiannya. Pariwisata sudah menjadi kesatuan yang tidak bisa dipisahkan dari maysarakat dan sudah menjadi kebutuhan yang wajib untuk dilakukan. Maka dari itu melalui sektor pariwisata masing-masing daerah meningkatkan wisata alam maupun budaya untuk meningkatkan perekonomian. Metode yang digunakan dalam penelitian ini adalah dengan menggunakan metode deskriptif paradigma kualitatif melalui beberapa tahapan yaitu observasi pendahuluan, wawancara dan dokumentasi yang berkaitan dengan strategi komunikasi pemasaran yang dilakukan oleh Dinas Pariwisata, Pemuda dan Olahraga Kota Singkawang. Peneliti melakukan wawancara dengan beberapa narasumber yang sesuai untuk menjawab masalah penelitian. Hasil penelitian menunjukkan bahwa strategi komunikasi pemasaran yang dilakukan oleh Disparpora untuk mengembangkan sektor pariwisata dimulai dengan melakukan tahapan pendataan, perencanaan, dan pelaksanaan. Selanjutnya, terdapat media-media baru yang lahir dalam Komunikasi pemasaran yang dilakukan oleh komunikator maupun komunikan dalam mengembangkan promosi yang dilakukan yaitu dari pihak swasta maupun dari masyarakat sehingga melahirkan identitas dalam keberagaman pariwisata dan budaya yang ada di Kota Singkawang.
\end{abstract}

Kata kunci: Pariwisata dan Budaya, Promosi, Identitas, Komunikasi Pemasaran, Media Social.

\begin{abstract}
Most of every region in Indonesia is now aware of the importance of tourism to progress in developing the potential of the region. Not only to promote tourism, but also for economic growth for the people of the area. Then from that point on, tourism is also not like it used to be but it has increasingly developed its meaning not only for recreation but for its broader meaning. Tourism has become a unity that cannot be separated from society and has become a necessity that must be done. Therefore through the tourism sector each region increases natural and cultural tourism to improve the economy. The method used in this research is to use a qualitative paradigm descriptive method through several stages, namely preliminary observations, interviews and documentation relating to marketing communication strategies carried out by the Department of Tourism, Youth and Sports in Singkawang City. The researcher conducted interviews with several suitable sources to answer the research problem. The results showed that the marketing communication strategy undertaken by Disparpora to develop the tourism sector began with the data collection, planning, and implementation stages. Furthermore, there are new media that were born in marketing communications conducted by communicators and communicants in developing promotions carried out, namely from the private sector or from the community so as to give birth to an identity in the diversity of tourism and culture in the City of Singkawang.
\end{abstract}

Keywords: Tourism and Culture, Promotion, Identity, Marketing Communication, Social Media. 


\section{PENDAHULU}

Indonesia merupakan negara yang mempunyai keanekaragaman yang sangat kaya yaitu terdiri dari beragam macam etnis, ras, budaya yang tersebar diberbagai pulau di seluruh Nusantara. Keberagaman etnis dan budaya membuat bangsa Indonesia memiliki kekayaan budaya yang menjadikan bangsa Indonesia cenderung terbuka terhadap pendatang dan perubahan. Komunikasi cenderung berlangsung efektif sehingga melahirkan sikap menerima, toleransi dan menghargai budaya lain yang pada gilirannya mampu membangun hubungan harmonis diantara orang-orang yang berbeda latar belakang budaya.

Wilayah Indonesia dari Sabang hingga Merauke adalah salah satu yang menjadikan berbagai macam ragam etnis, suku, budaya, dan juga wisata. Keanekaragaman wisata yang dimiliki Indonesia membuat negara kita banyak didatangi pengunjung untuk menikmati keanekaragaman etnis, wisata budaya, wisata alam dan wisata budanyanya. Hal ini justru mendapatkan hal positif untuk Indonesia dan masyarakat karena semakin berkembangnya pariwisata maka akan semakin menguatkan pariwisata yang ada di seluruh wilayah Indonesia.

Keberagaman suku bangsa atau etnis ini di satu sisi membawa pengaruh positif untuk kekayaan wisata, kebudayaan, seni, serta dinamika sosial kehidupan masyarakat Indonesia. Setiap daerah masing-masing memiliki keunikan dalam wisata dan budaya sehingga menjadi daya tarik tersendiri. Salah satu daerah yang mempunyai keberagaman wisata dan budaya adalah Kota Singkawang, Provinsi Kalimantan Barat.

Letak Kota Singkawang yang strategis, membuat potensi wisata yang ada semakin banyak dan berkembang. Sebagai daerah yang menyimpan banyak potensi wisata alam dan juga wisata budaya, Kota Singkawang semakin meningkatkan dan mengembangkan pariwisata di daerahnya terutama dengan menggencarkan kegiatan promosi pariwisata baik itu iwsata alam, wisata budaya dan juga potensi-potensi wisata yang ada.

Promosi pariwisata merupakan bentuk komunikasi pemasaran dalam pariwisata yang tujuannya adalah untuk memengaruhi target wisatawan agar berkunjung wisata ke daerah yang dipromosikan. Sebagai bentuk komunikasi, promosi membutuhkan strategi agar dapat memperoleh hasil yang maksimal dan tepat sasaran. Strategi promosi sendiri berkaitan dengan kemampuan pemasaran pariwisata dalam membuat langkahlangkah promosi meliputi target pengunjung, tujuan promosi, pesan promosi, dan media-media yang digunakan sebagai alat promosi pariwisata tersebut.

Pariwisata Kota Singkawang sudah cukup dikenal masyarakat, namun harus terus dikembangkan karena masih banyak potensi pariwisata yang belum dimaksimalkan. Bahkan Menteri Pariwisata, Arif Yahya, meyakini Kota Singkawang memiliki potensi untuk dikembangkan menjadi daerah wisata kelas dunia (https://kalbar.antaranews.com). Untuk mencapai tujuan tersebut banyak hal yang perlu diupayakan, salah satunya dengan komunikasi pemasaran. Komunikasi pemasaran menjadi aspek penting dalam keseluruhan misi pemasaran, serta menentukan suksesnya pemasaran. Bahkan telah diklaim bahwa pemasaran di era 1990-an adalah komunikasi dan komunikasi adalah pemasaran, keduanya tidak terpisahkan (Shimp, 2003:4).

Peningkatan dalam mengembangkan potensi wisata maupun kunjungan wisatawan sekaligus untuk menunjang kelancaran kegiatan pariwisata di Kota Singkawang. Dalam hal ini peran Disparpora Kota Singkawang sangat berperan penting untuk mampu berdaya saing serta meningkatkan dan melestarikan pariwisata 
daerahOleh sebab itu, maka peneliti ingin mengkaji lebih dalam yang berkaitan dengan konsep komunikasi pemasaran dalam promosi yang dilakukan oleh Dinas Pariwisata, Pemuda dan Olahraga dalam upaya mencapai tujuan yang telah menjadi target sebelumnya.

\section{METODE PENELITIAN}

Penelitian ini menggunakan metode kualitatif yang bertujuan untuk mendapatkan gambaran yang menyeluruh serta mendalam berdasarkan situasi wajar dari kasus yang diteliti. Metode penelitian deskriptif kualitatif hanya memaparkan situasi atau peristiwa, tidak mencari dan menjelaskan hubungan, tidak menguji hipotesis atau membuat prediksi (Rakhmat, 2009:24).

Metode penelitian ini dianggap paling sesuai oleh peneliti untuk memberikan gambaran yang komprehensif mengenai strategi komunikasi pemasaran. Melalui metode ini peneliti berusaha membuat deskripsi dan analisis berbagai bentuk strategi komunikasi pemasaran dalam promosi pariwisata yang dilakukan oleh para stakeholder.

\section{HASIL DAN PEMBAHASAN \\ Strategi Komunikasi Pemasaran Dinas Pariwisata, Pemuda dan Olahraga Kota Singkawang}

Strategi oleh Pemerintah yaitu Dinas Pariwisata, Pemuda dan Olahraga melakukan penyusunan strategi dalam beberapa tahapan. Tahapan ini diharapkan dapat dengan baik berjalan lancara untuk mendukung strategi pemerintah dalam melakukan komunikasi pemasaran dalam promosi pariwisata. Adapun tahapan-tahapan dari strategi komunikasi pemasaran Disparpora yaitu:

\section{Tahap Pengumpulan Data}

Berdasarkan salah satu penetapan pencapaian kinerja Dinas Pariwisata, Pemuda dan Olahraga Kota Singkawang khususnya di bidang pariwisata, yaitu meningkatnya jumlah kunjungan wisata, tahap pendataan tersebut terekam dalam wawancara dengan Bapak Supardiyana selaku Kepala Bidang Pariwista :

"Kunjungan wisatawan di Kota Singkawang setiap tahun selalu ada peningkatan. Jadi peningkatan ini tentunya ada strategi-strategi yaitu pendataan potensi-potensi wisata oleh pemerintah kota singkawang melalui dinas pariwisata didalam memasarkan destinasi-destinasi ataupun event-event yang akan ada di Kota Singkawang“ (Wawancara : 8 Juli 2019).

Kunjungan wisatawan yang mengalami peningkatan dalam kurun beberapa tahun terakhir ini membuat pemerintah baik Disparpora dan jajaran instansi yang terkait dengan pariwisata kota Singkawang semakin fokus untuk meningkatkan lagi dalam kunjungan wisatawan maupun pelayanan. Hal ini dilakukan agar Kota Singkawang lebih menjadi dikenal oleh masyarakat tidak hanya lokal maupun nasional tetapi dunia internasional.

Proses pendataan ini juga tidak mempunyai rentang waktu yang khusus, karena media sosial dapat digunakan kapan saja dan di mana saja. Kemudian pendataan yang dilakukan dalam mengelola informasi dari masyarakat jadi bisa cepat untuk dikelola secara langsung. Maka dari itu, proses pendataan dalam tahap pertama tidak memerlukan jadwal tertentu.

\section{Tahap Perencanaan}

Salah satu kunci keberhasilan strategi adalah proses dalam menyusun perencanaan. Perencanaan merupakan langkah awal dalam mencapai tujuan yang 
jelas dan lurus, agar secara keseluruhan komponen dalam suatu instansi mengetahui dengan baik tujuan yang akan dicapai.

Dinas Pariwisata, Pemuda, dan Olahraga dalam membuat perencanaan, juga menjalin kerjasama dengan salah satunya yaitu Komunitas yang terekam pada wawancara dengan Bapak Rizki selaku Bidang Pengembangan SDM :

"Kalau di Singkawang ni ada Genpi (Generasi Pesona Indonesia) khusus yang buat viral-viral atau segala macam tukan tranding topic. Terus ada HPI (Himpunan Pramu Wisata) itu yang guide-guide yang lokal ada yang guide nasional. itu yang terkait langsung dengan pembinaan kita sih. Tapi komunitas bebasnya tu banyak lagi. Ada blogger Singkawang, komunitas fotografer Singkawang, ada yang dari guide itu masuk Genpi juga. Jadi orang-orangnya bisa itu-itu jak ni. Di Genpi juga, di HPI juga (8 Juli 2019).

Kerja sama dengan komunitas berdampak sangat baik untuk pariwisata kota Singkawang itu sendiri. Karena jaringan dari komunitas ini sangat luas dan dalam tahap perencanaan ini sangat mendukung pihak pariwisata yang juga menjadi pembina untuk komunitas tersebut. Suatu perencanaan dibuat oleh Dinas Pariwisata, Pemuda dan Olahraga Kota Singkawang juga berencana untuk berkoordinasi dengan para guideguide lokal untuk mendapatkan pelatihan pemandu wisata alam (EKOWISATA) untuk program Pengembangan SDM Pariwisata.

\section{Tahap Pelaksanaan}

Pelaksanaan merupakan suatu wujud dari perencanaan yang jauh sebelumnya telah dibuat. Tingkat keberhasilan suatu pelaksanaan dapat dilihat dari seberapa matang perencanaan tersebut. Pelaksanaan juga akan berjalan dengan baik apabila diimbangi dengan kerja sama antar instansi yang terkait maupun masyarakat dalam pengembangan kepariwisataan daerah.

Pelaksanaan promosi yang dilakukan Dinas Pariwisata, Pemuda dan Olahrga adalah usaha-usaha yang dilakukan untuk melaksanakan semua rencana dan kebijaksanaan yang telah dirumuskan dan ditetapkan dengan melengkapi segala fasilitas sarana dan prasarana yang diperlukan, siapa saja komunikatornya, dimana tempat pelaksanaannya, kapan waktu dimulainya, dan media apa yang digunakan serta pengaruh media tersebut.

Tahap pelaksanaan ini didukung oleh kerja sama dengan Kementrian Pariwisata dan juga diiringi dengan kerja sama yang baik antara Disparpora dengan Asosiasi pariwisata di Indonesia. Hal ini terekam dalam wawancara Bapak Supardiyana yaitu:

"Kegiatan promosi melalui asosiasi pariwisata kepada asosiasi-asosiasi lain di daerah lain di Indonesia ini saling menawarkan keunggulan daerahdaerah sehingga mereka akan menawarkan dalam penjualan dalam bentuk paket2 wisata, dan ini ternyata sangat efektif karena apa salah satu bukti pada sebuah event salah satu contoh di kota Singkawang adalah Cap Go Meh, asosiasi pariwisata yang ada di Bali itu bisa membawa tamutamunya baik dalam negeri maupun manca negara diarahkan ke sini. Ini salah satu bukti nyata bahwa kerja sama asosiasi dari berbagai daerah sangat menguntungkan apabila dari event-event layak jual (Wawancara : 8 Juli 2019).

Pada penuturan di atas, terlihat kekuatan di antara masing-masing Asosiasi Pariwisata yang dapat meningkatkan pengunjung wisatawan secara signifikan. Kerja sama yang telah dilaksanakan diharapkan dapat berjalan secara berkala, karena pengaruh yang besar dalam kerja sama ini yang harus dipertahankan. 
Tahap pelaksanaan dalam strategi komunikasi pemasaran yang dilakukan oleh Dinas Pariwisata, Pemuda dan Olahrga menjadi hasil dari tahap pendataan dan perencanaan. Strategi komunikasi pemasaran sebagai wujud dalam upaya mengembangkan sektor pariwisata daerah, Disparporaa menyesuaikan pada pendataan dan perencanaan yang sebelumnya telah dibuat terlebih dahulu. Menjaga ketertiban, kemanan, dan lingkungan serta meningkatkan fasilitas sarana dan prasarana demi kenyamanan wisatawan saat mengunjungi objek wisata yang dikembangkan.

\section{SIMPULAN}

Berdasarkan hasil dalam penyajian data di atas, diperoleh tentang proses dalam tahapan-tahapan promosi yang dilakukan oleh Dinas Pariwisata, Pemuda dan Olahraga dalam mengembangkan sektor pariwisata Kota Singkawang. Terdapat tiga tahapan yaitu, tahap pendataan, perencanaan dan pelaksanaan. Ketiga tahap ini merupakan proses hasil dari konsep komunikasi pemasaran dalam melakukan promosi pariwisata Kota Singkawang. Yang pertama adalah melakukan pendataan wisata maupun potensi wisata, kemudian promosi yang adalah melakukan kerjasama antar komunitas lokal hingga nasional untun berbagai event besar yang ada di Kalimantan Barat khususnya Kota Singkawang yaitu Perayaan Tatung yang diadakan setahun sekali setelah perayaan Imlek.

\section{DAFTAR PUSTAKA}

Herat, Rizki Andini dkk. 2015. Peran Bidang Promosi Dan Pemasaran Dinas Pariwisata Kabupaten Pulau Morotai Dalam Mempromosikan Potensi Pariwisata Kabupaten Pulau Morotai. E-journal Acta Diurna, 4 (4). Diperoleh melalui https://media.neliti.com/media/publications/89559-ID-peran-bidang-promosi-danpemasaran-dinas.pdf

Hermawan, Agus. 2012. Komunikasi Pemasaran. Jakarta: Penerbit Erlangga.

Linasari, Festi dkk. Komunikasi Pemasaran Pariwisata Dan Kunjungan Wisatawan Di Bangkalan.Diperoleh sby.ac.id/index.php/representamen/article/download/1455/1243

Rakhmat, Jalaludin. 2009. Metode Penelitian Komunikasi. Bandung: PT Remaja Rosdakarya

Shimp, Terence A. 2003. Periklanan Promosi, Aspek Tambahan Komunikasi Pemasaran Terpadu. Jakarta : Erlangga.

https://kalbar.antaranews.com/berita/373923/menpar-siap-angkat-pariwisata-singkawang-jadikelas-dunia 